\title{
Web 2.0 in the Archival Domain: Why and How in the Knowledge Economy
}

\author{
TRIANTAFILLIA KOURTOUMI, PH.D. \\ Sr Archivist - Ex Director, The Historical Archives of Macedonia, The General State Archives of Greece \\ e-mail: frini95@yahoo.gr
}

Web 2.0 in the Archival Domain: Why and How in the Knowledge Economy?

\begin{abstract}
In the knowledge economy Web 2.0 applications used by archives are on the increase. This growing engagement has been having an influence on the way archival services and products are made available. In this article we aim to describe how Web 2.0 can work as a virtual extension for archives, by identifying impacts and benefits resulting from that innovation. The innovation is considered as inevitably linked to change and presents a number of challenges. The challenges can typically be brought together in three main areas: the technological change, the cultural change and the pedagogic change. These are all important, interdependent and must be addressed in both a strategic and an operational way if archives are to generate maximum benefit from their investment in this new communicating delivery mechanism. We restrict the attention to archival evidence-based knowledge, and examine issues in content, metadata quality, and knowledge dissemination policy that are important from the perspective of archival methodology.
\end{abstract}

Key words: archives, knowledge economy, Web2.0

Web 2.0 in ambito archivistico: come e perché nell'economia del sapere?

\section{SINTESI}

Nell'economia del sapere Web 2.0 le applicazioni utilizzate dagli archivi sono in aumento. Questo crescente impegno ha avuto un'influenza sul modo in cui prodotti e servizi di archiviazione sono resi disponibili. In questo articolo ci proponiamo di descrivere come il Web 2.0 può funzionare come un'estensione virtuale per gli archivi, identificando gli impatti ed i vantaggi derivanti da tale innovazione. L'innovazione è considerata come inevitabilmente legata al cambiamento, e presenta una serie di sfide. Le sfide in genere possono essere riunite in tre aree principali: il cambiamento tecnologico, il cambiamento culturale ed il cambiamento pedagogico. Questi sono tutti importanti, interdipendenti e devono essere affrontati in un modo strategico ed in un modo operativo se gli archivi devono generare il massimo beneficio dal loro investimento in questo nuovo meccanismo di consegna comunicante. Abbiamo limitato l'attenzione alla conoscenza basata sulle evidenze archivistiche ed esaminato le questioni nel contenuto, nella qualità dei metadati e nella politica di diffusione della conoscenza che sono importanti dal punto di vista della metodologia archivistica.

Parole chiave: archivi, economia della conoscenza, Web2.0

Web 2.0 v arhivih: Zakaj in kako v gospodarstvu temelječem na znanju?

\section{IZVLE ČEK}

V ekonomiji znanja je uporaba Web 2.0 aplikacije v porastu. Ta rast ima vpliv na način uporabe arhivskih storitev in izdelkov. Clanek z opredelitvijo vplivov in koristi, ki izhajajo iz te inovacije opisuje, kako lahko Web 2.0 deluje kot virtualna razširitev za arhive. Inovacija je neizogibno povezana s spremembami in predstavlja številne izzive. Izzive lahko združimo na tri glavna področja: tehnološke spremembe, kulturne spremembe in pedagoške spremembe. Vse so pomembne in soodvisne in jih je potrebno obravnavati tako na strateški in operativni način, $\mathrm{da}$ bi arhivi od naložbe $\mathrm{v}$ te nove komunikacijske mehanizme lahko pridobili čim več koristi. $V$ članku bomo pozornost omejili na arhivsko znanje, in preučili vprašanja glede vsebine, kakovosti metapodatkov in politike razširjanja znanja, ki so pomembna z vidika arhivske metodologije.

Ključne besede: arhivi, na znanju temelječe gospodarstvo, Web2.0 
Triantafillia KOURTOUM: Web 2.0 in the Archival Domain: Why and How in the Knowledge Economy, 121-130

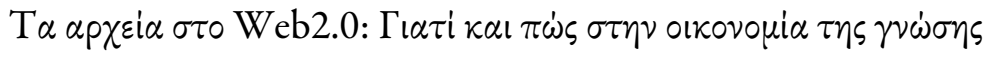

\section{ПЕРІАНЧН}

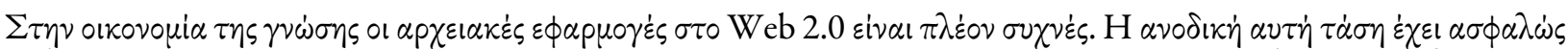

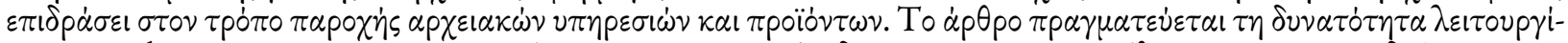

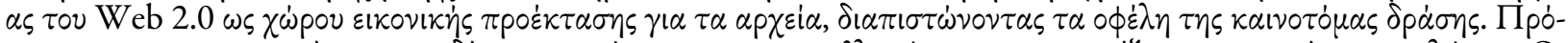

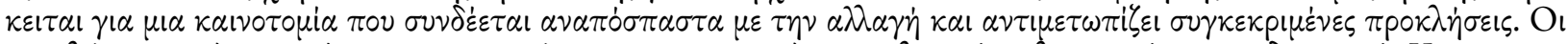

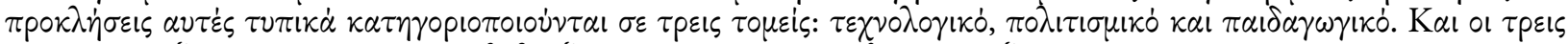

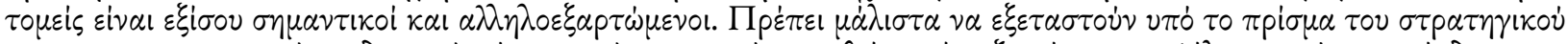

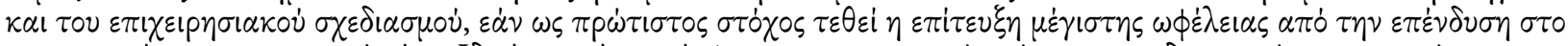

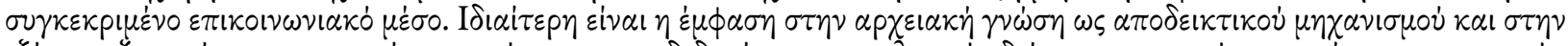

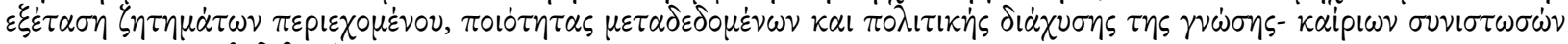
$\tau \eta \varsigma \alpha p x \varepsilon i \alpha \kappa \dot{s} \mu \varepsilon \theta 0 \delta 0 \lambda \circ \gamma i \alpha \varsigma$.

\section{Introduction}

In the information and communication technologies age (ICT) it is a commonly held belief that there has been an explosion of cultural data, information and knowledge in a global environment. But knowledge in any form is only of value when it can be used effectively and efficiently. The innovation of knowledge is increasingly being recognised as a key element in extracting its value. We need to understand how best to take knowledge through a series of stages from its creation to its use. It needs to be acquired, modelled and represented, stored and retrieved, used and reused, published and maintained.

Archivists, as groups of professional staff, are facing an uncertain future. Their traditional knowledge-based role as gatekeepers of their resources is under threat from many directions. In the 1960s \& 1970 s the position of subject professionals dealing with cultural information was designed to actively exploit and promote their institutions, their services and collections. Since that time there has been a rapid growth in Web based teaching and learning for delivery both on and off academic campus to be extended into broader communities of users. In the 1980s \& 1990s the support requirements for such a learning environment have severely tested traditional organisational structures. In the 2000s the array of technological conditions evolving e-culture (World Web \& Web1.0 - Semantic Web \& Web2.0) warned that archival management and service concepts needed to adapt to changes in teaching and learning methods, to the increasingly complex needs of "networked users", to the emerging situation of multiple information providers and to the many challenges presented by the internet (Jones \& $O$ ' Shea, 2004).

At the turn of the $21^{\text {st }}$ century, there are three basic communities for archival culture, namely (Veltman, 2003):

- archival organizations, which have content for which they provide a basic context

- research institutions, which provide context and communication for the content along with some software

- industry, which provides hardware and software for context and communication, and provides ways of exploiting content

In the knowledge economy ${ }^{1}$, archives as institutions are looking to redesign their traditional service delivery models in order to:

- downsize traditional services to free up resources for new priorities

- optimize financial and human resources

- collaborate with other learning providers

- respond to an increasing focus on flexible learning delivery

- transform themselves into learning resource centres to cater for users centred learning

1. We define the knowledge economy as production and services based on knowledge-intensive activities that contribute to an accelerated pace of technical and scientific advance, as well as rapid obsolesce (Powell \& Snellman, 2004). 
Along these lines, archives are using Web 2.0 applications in a context that allows for new types of interaction, new opportunities regarding institutional promotion, new ways of providing their services and making their heritage known to the community. Applications such as Facebook (online social network), Flickr (online image-sharing community) and YouTube (online video sharing community) are already used by archives that interact in the informal context of Web 2.0 (Nogueira, 2010). That innovation is inevitably linked to change and presents a number of challenges. The challenges can typically be brought together in three main areas: technological change, cultural change and pedagogic change. These are all important, interdependent and must be addressed in both a strategic and an operational way if archives are to generate maximum benefit from their investment in this new delivery mechanism (see Tab.1).

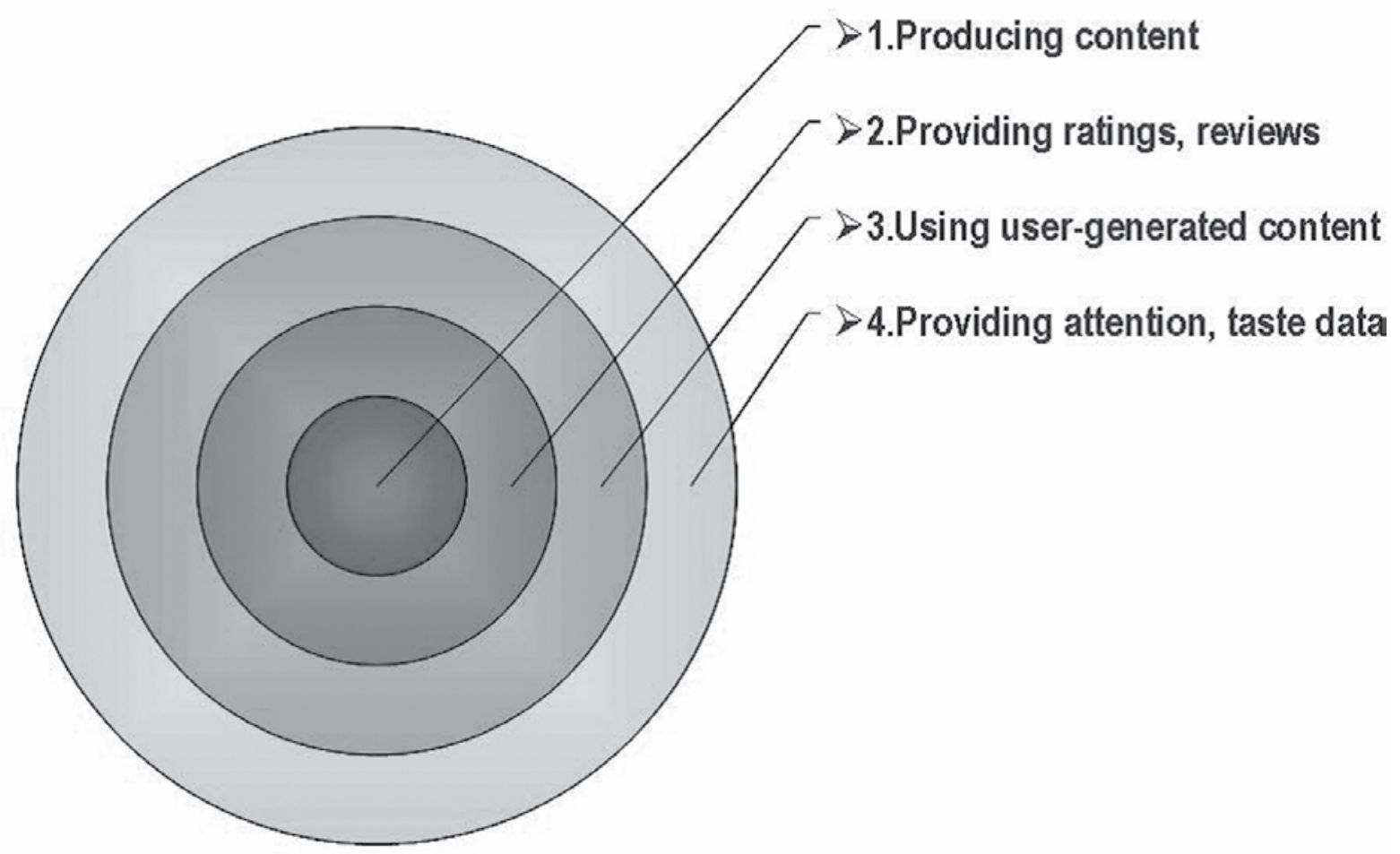

Tab.1: Delivery mechanism for archival content

\section{Technological change: dividing the lines between information and knowledge services}

Archives as memory institutions fulfill a central role in society as fabric of heritage, tangible links with the past and public content providers. Seen as a whole this immense amount of ever growing data treasured in their repositories shapes our social identity and constitutes the perception of our past, present and future (Boylan, 2002). In the last three decades, due to vast technological changes, archival institutions as concepts and as organizations have experienced radical shifts in their nature and structure throughout the world. While moving from the physical to the digital world, the distinctions between text and image, object and artefact appear to diminish. In the digital world, all of the objects that can access via the Web have been imbued with the ability to speak. Whether the object in question is a text file, an audio file, an image file, or a web page- all have the ability to speak. They all carry a message of some significance. In converting them from physical to digital form, they have been expressly delegated the ability to speak (Martin, 2002). 
In this view, the message the archival object carries can be traced as physical information (associated with pattern), biological information (associated with meaning), and social information (associated with understanding). In an influential paper from 1991, Buckland distinguished three uses of the term "information":

- Information-as-thing, where information is associated with a document

- Information-as-process, where the information is that which changes a person's knowledge state

- Information-as-knowledge, where information is equated with the knowledge which it imparts

From the information-as-thing viewpoint, archival information is regarded as physical and objective, or at least as being "contained within" physical documents and essentially equivalent to them. The other two meanings treat information as abstract and intangible. In-formation-as-process underlies theories of information behaviour which have a focus on the experience of individuals. Information-as-knowledge invokes the idea, well-trodden in the information area, that information and knowledge are closely related (Bawden and Robinson, 2012). There rests the distinction between information services and knowledge services that makes the difference (Cunningham, 2002). The distinction is real, substantive, and widely accepted in practice. Just two decades ago in a position paper for the WWW4 (4th World Wide Web conference, Boston, 1995), Farquhar (1995) of the Stanford University Knowledge Systems Lab observed,

\begin{abstract}
"Today the Web is rightly generating a tremendous amount of excitement. It gives us rapid access to information that we could not have found before. Tomorrow, however, we will expect even more than instant access. We will want software tools that will use that information to solve problems. We will want to turn that information into knowledge".
\end{abstract}

In theory, though, defining the difference between information and knowledge services is rather difficult because both are pervasive and because the terms are often used interchangeably. In addition, users often have different perceptions of whether a particular chunk of recorded information is actually "knowledge." And recorded knowledge obviously contains lots of information (Murray \& Barclay 1997). Apart from the increase in the number of users reached in archival knowledge services, there are, then, other less immediate but nonetheless beneficial effects from the use of Web 2.0 applications (Cao, 2009):

- increased importance of the archive to the user

- improvement in the archive's image

- potential of new interactive services to raise the level and quality of the service provided

- increased involvement of users and improved communication of the archive with such users

- improvement in communication among archivists

- greater ability to find quick solutions to meet the needs of users

- improvement in shared knowledge and collaboration

However, the radical changes have significantly altered traditional practices and employment paths followed so far by archival institutions. Rather than just focusing their efforts on the growth and care of their collections (=managing their information capital), cultural actors are being transformed into institutions that provide innovating services to the public (=managing their knowledge capital). It is generally admitted that "the most fundamental change which has affected archives ... is the now almost universal conviction that they exist in order to serve the public" (Boylan, 2001).

Along these lines, perhaps we can identify the unique characteristics of knowledge services to be offered from archives by exploring them from several perspectives:

- What happens in the "knowledge service transaction" from the archive to the user? What are the effects of knowledge services on the knowledge-seeker?

- What are the key characteristics of "knowledge service" in the archival institutions?

- Is our model for knowledge and learning changing as a result of technology in the knowledge service-based institution? 


\section{Cultural change: shifting the boundaries of archives}

Information seeking is a process that has been thoroughly researched in its entirety, and is best explained by several models that have been created and adapted to represent it. These range from behavioural and process, to cognitive models. We know from both information seeking and information retrieval research that "information systems ought to be highly iterative and interactive". As users of electronic libraries look for information they implement several strategies to help them find the information they require. These strategies may be analytical (more direct and structured) or browsing (more opportunistic and less structured) in nature. The information seeking process begins when one decides that there is a gap in his/her knowledge. This has been referred to as an anomalous state of knowledge. The information seeking process will then continue to exist until the seeker is either satisfied with the information required, or abandons the process (Granka et al, 2004).

As archival objects are digitised, stored, mediated by databases and networks, filtered by search engines, and shaped by software and technology design, information itself becomes available in new ways. Since evidence-based metadata, data quality and dissemination policy are important, from the perspective of methodology standards like the open archives metadata harvesting protocol are already in place; great progress is also made on the standards for the underlying metadata itself (Lynch, 2001). The thinking about digital preservation over the past decades is advancing to the point where the needs are widely recognized and well defined, the technical approaches at least superficially mapped out, and the need for action is clear enough. This redeployment is transforming human capacity to know, experience, and participate in archival culture, from seemingly simple issues about what a person can access and share to more subtle questions about how this new cultural field is represented, e.g., what kinds of cultural activity are made visible and invisible through databases and search engines, and to whom (Hudson, 2001). Despite the importance of this transformation, and as archival information itself becomes available in new ways, institutions are only beginning to ask serious questions about its characteristics, patterns of inclusion and exclusion, and implications for the future (Malhotra \& Galletta, 2004). The development of free, publicly accessible archival objects in a knowledge-based concept has demonstrated ways in which the network can change communication and patterns by altering dissemination and access methods for usable information.

Defining archival knowledge as usable information, it is crucial to estimate the meaning of "usable". If information is usable, then that information can be matched with, and brought to bear upon, the particular problems archives are addressing. To turn archival information into knowledge, it is necessary to understand the connections between it and archival institutions' processes. It is necessary to understand what information to use when, how to find it, and how to present it to the relevant people. The adoption by archives of Web 2.0 applications are a signal recognition of their potential: the "immediacy" factor; the support of exchange of views and the creation of new means of communication with the public; the opportunity afforded users to add extra information to content (text, images, audio and video); access to primary sources over the Web; the broadening of their audience; the potential of new ways of providing access; and, raising the institutional profile within the user community. (Davies \& Gregersen, 2010).

That procedure leads to the creation of a strong conviction: the primary characteristic that archival institutions hold is that they all are social agencies supporting public inclusion through providing primitive information. All are about the critical work of creating and supporting users. All institutions invite purposeful use and forge links to the world beyond their walls. They are both embedded in their communities and frequently acknowledged as trusted content and knowledge providers in a global environment. Each of their applications of Web2.0, either in Facebook, Flickr, Twitter or in YouTube, among others, represents an individual context of use and allows a set of specific functionalities within a new rationale of democratization in the production of content and access thereto, through interactive and collaborative platforms where anyone can be an author, publish and access content freely (Kourtoumi, 2004).

Learning from the disappearing boundaries, implications for the practice of the archivists may be redefined. One of the biggest challenges for archives in the knowledge economy is to keep abreast of the increasing speed of technological development and to act accordingly. Consequently, first and foremost, archival institutions must anticipate a convergence, not only of terminology and practice, 
Triantafillia KOURTOUM: Web 2.0 in the Archival Domain: Why and How in the Knowledge Economy, 121-130

but also of values (Smith, 2000). It is important for them to foster collaboration. This collaboration is mostly recognition of intersecting nodes of interest, activity and mission and less a joined at the hip partnership. It is mainly a cooperation emerging as the strategy of the 21 st century, aligned with how archival institutions are thinking about their communities as holistic environments, as social ecosystems in which their users are part of an integrated whole (Kourtoumi, 2005).

This common agreed action plan aims to provide a favourable environment for digital investment in the archival content in order to boost productivity, to modernise public services and notably education, and last but not least, to give everyone one the opportunity to participate in the global knowledge economy. This is the key message behind this action plan. In light of the impact of networked digital information technology it appears to be especially clear that the collections of archives are all ultimately documents-things that professionals have imbued with the ability to create usable information; thus, professionals evolve them into valuable tools for innovation in the democratization process.

\section{Pedagogic change: defining the view on e-learning from archives}

Pedagogic change can be seen in the breakthrough of archival communication technology, the short lifecycle of information and, as a result of these, a new view on learning. Learning is not anymore confined to institutions such as schools and colleges. Knowledge economy can offer all members of society the opportunity to match learning to their specific needs and circumstances. Education is no longer seen as a non-recurring investment with the purpose to educate people for a profession they will practice for a long time, but as a lifelong process ${ }^{2}$. It may or may not involve obtaining a formal qualification. It ranges from pre-school years to post-retirement, from formal learning in schools and universities, through vocational training in workplaces, to informal learning.

With learning becoming a way of living, the learner, not the teacher, is cantered in the key position. Information is something every individual builds, and it cannot directly be communicated from one individual to another. This way of thinking looks upon knowledge as the understanding of a phenomenon and learning as the process where this understanding develops. According to this view the user is active and creates his own knowledge. Information seeking becomes an important part of learning and the borders between the process of information seeking and the process of learning vanishes (Broberg et al., 1999). The base for the individual ability to understand and use information is a qualitative, ongoing learning process. Information seeking is an important part of the learning process and information resources become the base for lifelong learning. In this framework the content of archives in digital access can be seen as a global library, a social context, where the people interact for learning purposes. The role of archives is defined as an important knowledge resource from trustworthy material, being intergraded into the general information structure of the society. Many archives are proactive learning institutions, using their storehouses of learning materials for the benefit of their users.

However, all archives need to respond to policies and developments, which are acting as drivers for change. With the Web2.0 access offering an excellent environment for learning information handling and critical assessment, the development and use of e-learning based information resources from archival repositories are growing fast. In the academic world, for example, archival resources are offered quite frequently and virtual archival centred education cyberspaces, as new e-learning environments, are planned and realised all over the world. Learning in the virtual environment seems to be very easy. Still the experience so far indicates that this is a big illusion. It would be generally both perverse and impractical to employ Web2.0 as the sole means of communicating with users or delivering learning. Education is a social process and social interaction between students and teachers is an essential part of high-quality learning. Even within the most formalized parts of educational processes such as assessment, there are many things which computers cannot yet do, such as assessment of verbal performance or aesthetic design. And there are many aspects of assessment which people currently do better than computers, such as offering guidance and explanations which are tailored to students' particular learning needs. To be successful in creating effective learning environments the virtual education space requires a new kind of knowledge-based ground, commonly accepted among both faculty and students and new forms of collaboration between teachers, pedagogical experts and archival information specialists.

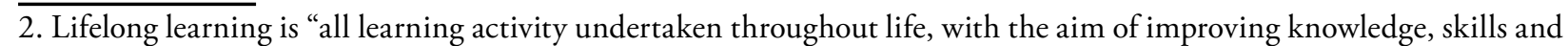
competence, within a personal, civic, social and/or employment-related perspective” (European Commission, 2001). 
On pedagogic grounds, then, the issue for archives is not a choice between conventional and elearning delivery methods, but a choice of the most appropriate balance between the uses of these different methods in different contexts. This is a process, which involves the professional judgment of educators (=providers of knowledge), taking into account the changing needs, demands, interests and capabilities of students (=consumers of knowledge). Meaningful information and knowledge are part of the same conceptual family. Information is converted to knowledge by being inter-related, a process that may be expressed through network theory. Informally, "what [knowledge] enjoys and [information] lacks ... is the web of mutual relations that allow one part of it to account for another. Shatter that, and you are left with a pile of truths or a random list of bits of information that cannot help to make sense of the reality that they seek to address (Froridi, 2011a). Furthermore, information that is meaningful must also be relevant in order to qualify as knowledge, and this aspect may be formally modelled, as also the distinction between "knowing", "believing", and "being informed" (Floridi, 2011b).

However, there is significant scope to enhance the quality and reach of education by appropriate and well-planned developments of e-learning. If an archival institution wishes to actively promote educational innovation in the use of e-learning, this must include both "bottom up" and "top down" features. There is no substitute for individual flair and creativity in devising novel and exciting ways to present course materials. But effective use of e-learning also requires institutions to put in place a range of policies, procedures and development activities; in short, to adopt a strategic approach to the deployment of e-learning. Archival institutions have much to gain by such an approach. Developing a clear and consistent institutional policy on matters such as the selection of virtual learning environments, and the specification of online materials, will help to create a coherent technical infrastructure for e-learning; will also minimize the effort for staff in complying with technical standards (Bawden, 2011).

Where an archival institution plans to make significant use of e-learning, it may be appropriate to extend the strategic approach to a systematic review of the entire curriculum. For example, staff in all programme areas could be encouraged to identify those learning outcomes where Web2.0 and knowledge economy-based delivery can add most value. The institution might then seek to concentrate its investment of staff time in the co-ordinated production of materials to support those curriculum areas. This approach might deliver economies of scale and ensure that the creative efforts of staff are focused on activities that can generate greatest benefits for student learning.

Therefore, archival institutions should:

- ensure that development of e-learning is led by user-student needs rather than technological potential or excitement

- Develop systematically policies, systems and infrastructure to both support and discipline the creativity and flair of individual academics. This may require centralization of some existing processes of course development and places, with very small marginal costs for each additional user

- enhance the scope for student-centred learning, through customizable access to materials, and enhanced interactivity, allowing choice of routes, learning styles, timing, repetition and self-pacing

- provide potentially rapid and easy access to a rich, diverse range of multimedia materials and resources, including simulations that would otherwise be impractical, uneconomic or unsafe to experience

- prioritize the curriculum areas, and/or aspects of the educational process where e-learning approaches would add most value and focus their development on these areas

- focus on development of good practice advice for institutions on e learning

- consider investing in collaborative/transformational e-learning developments, where they will benefit -national, trans-national, intra-European, global-scopes.

\section{Conclusions}

There is a wide spectrum of processes involved in Web2.0 applications offered by archives in the knowledge economy. Connectivity and equipment are no longer the central issues for archives. The 
focus moves to social networks, content, quality assurance and standards, information professional training and continuous development, organisational change and attendance of the transformations within the various technological, cultural and pedagogic processes. This growing engagement has been having an influence on the way services and products are made available, loosely termed Web2.0. The possible effects arising from the use of these applications are significant and have implications in areas crucial to archives, such as producing content, providing reviews, using user-generated content, providing attention. The increase in and diversification of users is one of the impacts that is most often referred to.

However, the adoption by archives of Web 2.0 applications are signal recognitions of their potential as the "directness" factor, defined as the support of exchange of views and the creation of new means of communication with the public. Some indicative applications of the potential of this immediacy are: the exchange of views and the creation of new means of communication with the public; the opportunity afforded users to add extra information to content (text, images, audio and video); the access to primary sources over the Web; the broadening of audience; the potential of new ways of providing access; and raising the institutional profile within the user community. Each application represents an individual context of use and allows a set of specific functionalities within a new rationale of democratization in the production of content and access there to, through interactive and collaborative platforms where anyone can be an author, publish and access content freely.

\section{Reference list}

Bawden, D. (2011). Mind the gap: transitions between concepts of information in varied domains. In: Information ecology and libraries conference, $10^{\text {th }}-12^{\text {th }}$ October 2011, Comenius University Bratislava, Slovakia.

Bawden, D.\& Robinson, L. (2012). Introduction to information science. London: Facet Publishing.

Boylan, Patrick (2001). A Revolution in Museum Management Requires a Revolution in Museum Professional Education and Training. In: Seminar of ICOM Committees for Management (INTERCOM), Museology (ICOFOM) and Training of Personnel (ICTOP), Barcelona. Available at http://www.city.ac.uk/ictop/boylan2001.html (accessed on 05.05.2015).

Boylan, Patrick (2002). Defining Museums and Galleries: A compilation of key, or particularly interesting or provoking, definitions of museums. In: City University London. Available at http://www.city.ac.uk/ictop/musdef.html (accessed on 05.05.2015).

Broberg, An., Milrad, M. \& Pederson, T. (1999). Challenges for Design: Seeing Learners as Knowledge Workers Acting in Physical - Virtual Environments. Journal of Courseware Engineering. Available at http://www.cs. umu.se/-bopspe/publications/JCE/ (accessed on 05.05.2015).

Buckland, M. K. (1991). Information as Thing. Journal of the American Society for Information Science, 42 (5), pp. 351-360.

Cao, Dongmei (2009). Chinese Library 2.0: status and development. In: Chinese Librarianship: an International Electronic Journal. Available at http://www.iclc.us/cliej/cl27cao.htm (accessed on 05.05.2015).

Cunningham, Stuart (2002). Culture, Services, Knowledge or is content King, or are we just drama Queens? In: Communications Research Forum. Available at http://66.102.9.104/search?q=cache:7vG1fwrjxKQJ:www. creativeindustries.qut.com/research/cirac/documents/CRFOct02.pdf+information+services++knowledge+servi ces+in+culture\&hl=el (accessed on 05.05.2015).

Davies, P., \& Gregersen, N.H. (2010). Information and the nature of reality:from physics to metaphysics. Cambridge: Cambridge University Press.

European Commission: Directorate-General for Education and Culture \& Directorate-General for Employment \&Social Affairs (2001). Making a European area of lifelong learning a reality. Available at http://europa. eu.int/comm/education/policies/lll/life/communication/com_en.pdf (accessed on 05.05.2015).

Farquhar, Adam (1995). KR and the Web. In: WWW4 by Stanford Knowledge Systems Lab, "Building Global Knowledge Webs; Knowledge Representation for the Web" Panel Session at the Fourth International Conference on the World Wide Web, Boston, December 11-14. Available athttp://www.w3.org/Conference/WWW4/Panels/ $\mathrm{krp} /$ farquhar.html (accessed on 05.05.2015).

Floridi, L. (2011a). Semantic conceptions of information. In: Zalta, E.N. (eds.), Stanford encyclopedia of philosophy (Spring 2011 edition). Available at http://plato.stanford.edu/archives/spr2011/entries/information-semantic (accessed on 05.05.2015). 
Triantafillia KOURTOUM: Web 2.0 in the Archival Domain: Why and How in the Knowledge Economy, 121-130

Floridi, L. (2011b). The philosophy of information. Oxford: Oxford University Press.

Granka, L., Joachims,T. \& Geri Gay,G. (2004). Eye-tracking analysis of user behavior in www search. In Special Interest Group on Information Retrieval, pp. 478-479.

Hudson, H. E. (2001). Access to the Digital Economy: Issues for Rural and Developing Regions.In: Telecommunications Management and Policy Program, University of San Francisco. Available at http://www.usfca.edu/ facstaff/hudson/papers/Access\%20to\%20the\%20Digital\%20Economy.pdf(accessed on 05.05.2015).

Jones, N. \& O'Shea, J. (2004). Challenging hierarchies: The impact of e-learning. Higher Education, 48 (3), pp. 379-395. Available at htpp://www.elearning-reviews.org/journals/higher-education (accessed on 05.05.2015).

Kourtoumi, Tr. (2004). Identity formation or historical knowledge transmittion? The european archival institutions in the information society and the new globality. In: Conference Proceedings, ECER 2004. Available at www.ece.uth.gr/OPENnet/conferences/ecer2004/fullpapers/kourtoumi.pdf (accessed on 05.05.2015).

Kourtoumi, Tr. (2005). Shifting Toward a Global Learning-Oriented Society: Semantic Applications in the Archival Heritage. In: Conference Proceedings, EVA Florence 2005, 14-18 March. Available at www.evaflorence. it/ e_programme.php-44k (accessed on 05.05.2015).

Lynch, Cl. (2001). Metadata Harvesting and the Open Archives Initiative. In: Association of Research Libraries, 217, pp. 1-9. Available at http://66.249.93.104/search?q=cache:Jb8JcfmalF8J:www.arl.org/newsltr/217/mhp.

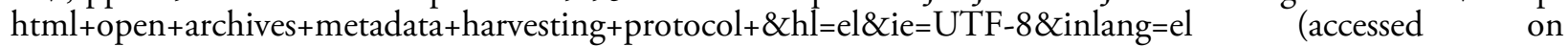
05.05.2015).

Malhotra, Y. \& Galletta, D. (2004). Building Systems That Users Want to Use. Communications of the ACM, 47 (12), pp. 89-94. Available at http://thomas.baudel.name/Epistemologie/p88-malhotra.pdf (accessed on 05.05.2015).

Martin, R. (2002). Blurring the Boundaries of Cultural Institutions, Natural Science Collections Alliance, Ph.D. Institute of Museum and Library Services, Washington, DC. Available at http://www.imls.gov/whatsnew/current/sp060702.htm (accessed on 05.05.2015).

Murray, Ph. \& Barclay, R. (1997). Information, Knowledge, and Document Management Technology. In: Knowledge Praxis Publications. Available at http://64.233.183.104/search?q=cache:KCfMFWgiaWIJ:www.ktic. com/topic6/12_INFKM.HTM+Information,+Knowledge,+and+Document+Management+Technology+\&hl $=$ el\&ie=UTF-8\&inlang $=$ el (accessed on 05.05.2015).

Nogueira, Marta (2010). Archives in Web 2.0: New Opportunities. Available at http://ariadne.ac.ik/issue63/ nogueira (accessed on 05.05.2015).

Powell, W. \& Snellman, K. (2004). The Knowledge Economy. Annual Review of Sociology, 30, pp. 199-220. Available at 10.1146/annurev.soc.29.010202.100037 (accessed on 05.05.2015).

Smith, Bernard (2000). Digital Heritage and Cultural Content. Russian Digital Libraries Journal, 3 (3) Available at http://64.233.183.104/search?q=cache:SuKXk8IFvqAJ:www.elbib.ru/index.phtml\%3Fpage\%3Delbib/ eng/journal/2000/part3/smithb+Smith,+Bernard+\%26\%238220\%3BDigital+Heritage+and+Cultural+Conte $\mathrm{nt} \% 26 \% 238221 \% 3 \mathrm{~B}+\mathrm{Cultural}+$ Heritage+Applications, +European+Commission,+Information+Society+Tec hnologies, \&hl=el\&ie=UTF-8\&inlang=el (accessed on 05.05.2015).

Veltman, Kim (2003). E-Culture, Art History and Museum Studies. Changing the way research is done. The user perspective on e-infrastructure, Brussels: European Commission, December, pp. 66-67. Available at ftp://ftp. cordis.lu/pub/ist/docs/rn/veltman.pdf (accessed on 05.05.2015).

\section{SUMMARY}

Archives are using Web 2.0 applications in a context that allows for new types of interaction, new opportunities regarding institutional promotion, new ways of providing their services and making their heritage known to the community. Applications such as Facebook, Flickr and YouTube are already used by archives that interact in the informal context of Web 2.0. That innovation is inevitably linked to change and presents a number of challenges. The challenges can typically be brought together in three main areas: technological change, cultural change and pedagogic change. These are all important, interdependent and must be addressed in both a strategic and an operational way if archives are to generate maximum benefit from their investment in this new delivery mechanism. Technological change estimates the radical changes that have significantly altered traditional practices and employment paths followed so far by archives. Rather than just focusing on the growth and care of their content, managing their information capital, archives are being transformed into institutions that provide innovating services to the public, managing their knowledge capital. Cultural change for archives states the 
Triantafillia KOURTOUM: Web 2.0 in the Archival Domain: Why and How in the Knowledge Economy, 121-130

anticipation of a convergence, not only of terminology and practice, but also of values. It is important to foster collaboration. This collaboration is mostly recognition of intersecting nodes of interest, activity and mission and less a joined at the hip partnership. It is mainly a cooperation emerging as the strategy of the $21^{\text {st }}$ century, aligned with how archival institutions are thinking about their communities as holistic environments, as social ecosystems in which their users are part of an integrated whole. Pedagogic change can be seen in the breakthrough of archival communication technology, the short lifecycle of information and, as a result of these, a new view on learning. On pedagogic grounds, then, the issue for archives is not a choice between conventional and e-learning delivery methods, but a choice of the most appropriate balance between the uses of these different methods in different contexts. This is a process, which involves the professional judgment of educators, as providers of knowledge, taking into account the changing needs, demands, interests and capabilities of students, as consumers of knowledge. Meaningful information and knowledge are part of the same conceptual family. Information is converted to knowledge by being inter-related, a process that may be expressed through network theory.

Typology: 1.02 Review Article

Submitting date: 04.03.2015

Acceptance date: 09.04.2015 